\title{
Changing role of middle income economies in contem- porary international trade: comparative analysis
}

\author{
Marcin Gryczka
}

\begin{tabular}{|c|c|}
\hline \multicolumn{2}{|r|}{ A B S T R ACT } \\
\hline \multicolumn{2}{|c|}{$\begin{array}{l}\text { Objective: The purpose of this paper is to analyze selected international trade indica- } \\
\text { tors, and then to verify, if assumption of growing importance of middle income econo- } \\
\text { mies (according to the World Bank classification) can be justified. }\end{array}$} \\
\hline \multicolumn{2}{|c|}{$\begin{array}{l}\text { Research Design \& Methods: Article consists of two main parts. In the former some } \\
\text { shifts in international merchandise trade in } 1995-2018 \text { have been analyzed. In the latter } \\
\text { the assessment of selected trade indicators has been included, with particular regard } \\
\text { to those, which could be utilized as a basis for verification of growing importance of } \\
\text { middle income countries in international trade. }\end{array}$} \\
\hline \multicolumn{2}{|c|}{$\begin{array}{l}\text { Findings: Between } 1995 \text { and } 2018 \text { there was a noticeable improvement of middle income } \\
\text { countries' share in global merchandise trade, and their competitive advantage improved } \\
\text { dramatically. As confirmed by RCA index analysis, middle income economies improved sig- } \\
\text { nificantly in all manufactures, and was particularly high in labour-intensive and resource- } \\
\text { intensive manufactures, as well as in low-skill and technology-intensive manufactures. }\end{array}$} \\
\hline \multicolumn{2}{|c|}{$\begin{array}{l}\text { Contribution \& Value Added: Analyses concerning economy groupings are still rela- } \\
\text { tively rare, especially in Polish economic literature. Therefore the presented research } \\
\text { can be perceived as a quite fresh approach in this field. Finally, usage of wide collection } \\
\text { of trade indicators for verification of middle income economies' international signifi- } \\
\text { cance should also be treated as a strength of presented paper. }\end{array}$} \\
\hline Article type: & \\
\hline & es; in \\
\hline & \\
\hline & \\
\hline
\end{tabular}

\section{Suggested citation:}

Gryczka, M. (2020). Changing role of middle income economies in contemporary international trade: comparative analysis. International Entrepreneurship Review (previously published as International Entrepreneurship / Przedsiębiorczość Międzynarodowa), 6(1), 93-107. https://doi.org/10.15678/IER.2020.0601.06 


\section{INTRODUCTION}

In recent decades there was a noticeable geopolitical shift in global economy, i.e. growing importance of so called newly industrialized, especially Asian economies. Despite the global protectionism awakening, integration process slowdown (and even its reversion in case of NAFTA), increasing economic imbalance and social inequality, as well as urgent climate change related problems, another developing countries have strived to catch up not only leading Asian economies, but some of developed ones as well. The main purpose of this paper is to analyze selected international trade indicators, and then to verify, if assumption of growing importance of middle income economies (according to the World Bank classification) can be justified. Research covers the years 1995-2018, where applicable, and utilized data have been derived from different statistical sources, like the United Nations Conference on Trade and Development (UNCTAD), World Bank, and WTO databases. In the article selected methods of descriptive statistics (like analyses of trend, composition, and dynamics), as well as some statistical measures, like international division of labor engagement, trade coverage, revealed comparative advantage (RCA) and concentration indices have been employed. The low and lower middle income economies are the primary subjects to be investigated, and selected high income countries and groups are used in some cases for comparative purposes only.

\section{LITERATURE REVIEW}

According to the United Nations, there is no established convention for the designation, if given country or area should be included either in "developed" or "developing" territory group. The terms "developed" and "developing" are intended mostly for statistical convenience and do not necessarily express a judgement about the stage reached by a particular country or area in the development process (UNSD, 2019). Moreover, it should be explicitly stressed, that so called developing countries are very diversified, if we took into consideration for example GDP per capita, infrastructure development, world trade achievements, poverty and education inequities and so on.

Nevertheless, one of developing country definitions says, that this is a country with a less developed industrial base and a low Human Development Index (HDI) relative to other countries (O'Sullivan \& Sheffrin, 2003). One could expand this definition by adding relatively low GDP per capita in such countries, but this short description will not be universally agreed upon. Naturally, meant in this manner developing countries tend to have some common features, like low levels of access to safe drinking water, sanitation and hygiene, energy poverty, high levels of pollution, poor infrastructure (especially ICT infrastructure), low education levels, high rate of corruption, high "climate vulnerability" and its negative implications (Bruckner, 2012; Fischer et al., 2002; Mertz et al., 2009).

It's worthy to mention the most important and perceptible difference between "developed" and "developing" countries. The former are usually considered as quite rich, especially with respect to their gross domestic product per capita, well equipped with physical and human capital, characterized by solid socio-political systems, and most of all located at the top of world's most innovative economies (Cornell University et al., 2019). 
Therefore their current development stage can be perceived as quite static - they are simply leaders motivated, first and foremost, to defend the status quo.

Table 1. World Bank classification for selected years in 1990-2018

\begin{tabular}{|l|c|c|c|c|}
\hline \multirow{2}{*}{ Income group } & \multicolumn{4}{|c|}{ Gross National Product (GNP) per capita(in USD) } \\
\cline { 2 - 5 } & $\mathbf{1 9 9 0}$ & $\mathbf{2 0 0 0}$ & $\mathbf{2 0 1 0}$ & $\mathbf{2 0 1 8}$ \\
\hline Low income & $<=545$ & $<=760$ & $<=975$ & $<=1,025$ \\
\hline Lower middle income & $546-2,200$ & $761-3,030$ & $976-3,855$ & $1,026-3,995$ \\
\hline Upper middle income & $2,201-6,000$ & $3,031-9,360$ & $3,856-11,905$ & $3,996-12,375$ \\
\hline High income & $>6,000$ & $>9,360$ & $>11,905$ & $>12,375$ \\
\hline
\end{tabular}

Source: World Bank 2020a.

For that reason same years ago the World Bank decided to no longer distinguish between "developed" and "developing" countries in the presentation of its data, considering the two-category distinction obsolete. Instead, this international organization divides countries into four groups based on one clear criterion, i.e. gross national income per capita. ${ }^{1}$ Although this classification had been internally used for analytical purposes since late eighties of 20th century, only very recently it has turned into World Bank official standpoint (Prydz\& Wadhwa, 2019). It should be therefore added, that GNI per capita thresholds are verified and amended every year (see Table 1).

Growing importance of middle income economies, especially China and other Asian economies, was reflected in the literature on the subject mainly in two recent decades. In addition to the research concerning comparative advantage and global trade shifts of those countries (Hanson, 2012; Sposiat al., 2018), some analysis of the factors driving their economic growth can also be found (Su\& Yao, 2016).Another noticeable area of interest is so called middle-income trap, the phenomenon where rapidly growing economies stagnate at middle-income levels and fail to transform into a high-income economy, and its causal analysis (Bulmanat et al., 2016; Felipe et al., 2014; Griffith,2011).

\section{MATERIAL AND METHODS}

Statistical data used in the paper generally cover the period 1995-2018, where available. Results of the conducted research have been presented using mainly composition and dynamics analyses. Moreover, in the latter part of the paper, based on the definitions and methodology presented in the literature (Nakonieczna-Kisiel, 2010; UNCTAD, 2020), the following indicators have been utilized:

- average export rate,

- international division of labor engagement index,

- trade coverage (TC) index,

- revealed comparative advantage (RCA) index,

- product concentration index (Herfindahl-Hirschmann Index),

\footnotetext{
${ }^{1}$ In FY02, a change in terminology was made to be in line with the 1993 System of National Accounts (SNA); the definition of GNI per capita remains the same as the previously used gross national product (GNP) per capita (World Bank, 2020b).
} 
- intra-industry trade index (Grubel-Lloyd Index).

\section{Shifts in international merchandise trade in 1995-2018}

Predominance of high income, particularly so called "Golden Triad" (the USA, European Union, and Japan), and some upper middle income countries (like BRICS, but especially China) in the contemporary world economy is unquestionable, although even these economies has to face some serious globalization-related challenges (Department of Economic and Social Affairs, 2013; Ghosh 1996). Some of them are issues connected with climate change, growing power of transnational corporations and conflicts of interest between corporations and the state (with changing role of the latter). Advanced internationalization of production leads to creation of extensive supply chains, increasing thereby the overall risks for many stakeholders. Problems related to long and sophisticated supply chains can be predominant especially now, in times of ongoing trade wars and regional political instability (Dicken, 2011; VanGrasstek, 2013).

According to the latest World Trade Organization data, developing economies outperformed or equaled the performance of developed economies in world trade in most of the past ten years, which in turn led to their $44 \%$ share in world merchandise trade in $2018 .^{2}$ On the other hand, at the same time the top ten traders in merchandise trade accounted for a little over half of the world's total trade (WTO, 2019). Of course, looking only on those data a straightforward conclusion of still unquestionable predominance of developed countries could be drawn. Nonetheless, it's worthy to mention that only in 2005-2015 the share of developing economies in merchandise exports increased from 33 to 42 percent (WTO, 2016), and this was despite the negative consequences of 20082009 financial crisis for the global economy. Moreover, since 2011 developing economies' exports to other developing economies had surpassed its exports to developed economies, and "South-South" trade represented an estimated US\$ 4.28 trillion or 52\% of total developing economies' exports in 2018 (WTO, 2019).

Clear confirmation of those trends can be found in Figure 1. Between 1995 and 2005 merchandise combined share of middle income economy groups was almost the same (in imports) or was increasing in slow pace (in exports). By the end of first decade of XXI century merchandise trade share of economies in question grew by more than 10 percentage points, both in exports and in imports. As a result in 2018 lower middle and upper middle income economy groups were responsible for more than one third of global merchandise trade. It should be also considered that mostly BRICS countries, especially China, were the main source of upper middle economies advancements in that respect.

Between 1995 and 2018 there were visible changes in merchandise trade matrix, which have been presented in Table 2. In period under scrutiny lower middle and upper middle income countries significantly strengthened their bilateral exports, which in turn led to shrinking share of high income economies in their merchandise exports (by almost 15 percentage points). On the other hand, upper middle income economies increased their share in high income economies exports by ten percentage points.

\footnotetext{
2 World Trade Organization still uses quite "blurred" distinction between developed and developing countries, not taking into consideration World Bank classification based on income ranges.
} 

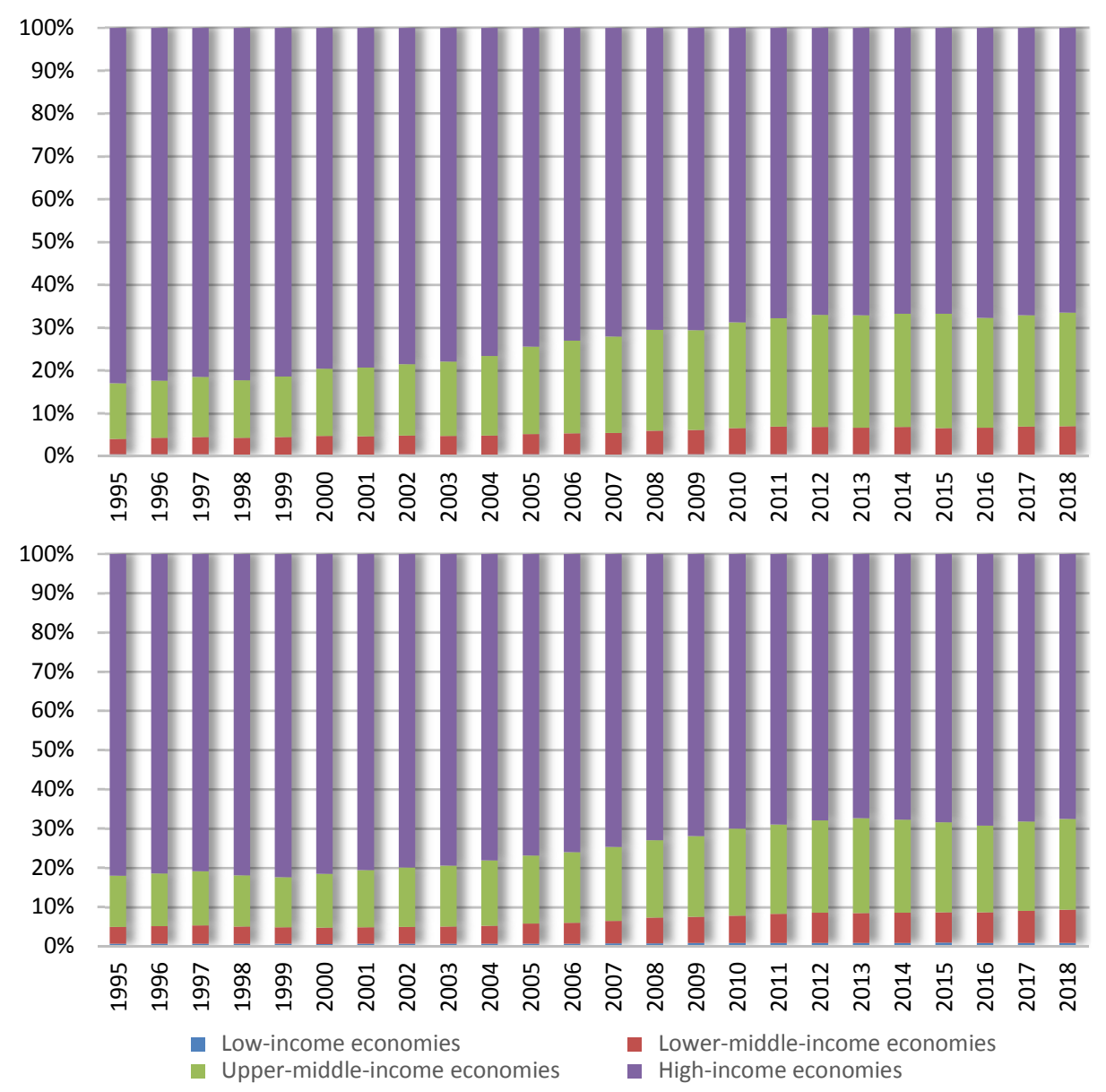

Figure 1. Merchandise trade shares in 1995-2018 (exports - upper chart, imports - lower chart) Source: UNCTAD database (2020).

As concerns merchandise imports matrix, importance of upper middle income economies, measured as a share in given economy group's imports, increased not only in both middle income groups, but in high income economies as well. In other words, in last 25 years there were at least two noticeable shifts in merchandise trade matrix - growing export and import shares especially of upper middle income economies, and decreasing shares of high income economies in all partner groups.

Looking at the merchandise export matrix by degree of manufacturing (see Table 3), it can be noted that in real terms lower middle income economies increased their exports to the highest extent in medium-skill and technology-intensive manufactures (inside this group and to high income economies) and high-skill and technology-intensive manufactures (to upper middle income economies). As regards upper middle income group, the evident advancements can be observed in all merchandise groups, with the only decline in labor-intensive and resource-intensive manufactures' exports to high income economies (by almost 30 percent). 
Table 2. Merchandise trade matrix in 1995 and 2018 (percentage)

\begin{tabular}{|c|c|c|c|c|c|c|c|c|c|c|}
\hline \multirow[b]{2}{*}{ Economy group } & \multicolumn{5}{|c|}{1995} & \multicolumn{5}{|c|}{2018} \\
\hline & LI & LMI & UMI & HI & Total & LI & LMI & UMI & HI & Total \\
\hline & \multicolumn{10}{|c|}{ Exports } \\
\hline $\mathrm{LI}$ & 3.8 & 9.6 & 18.1 & 68.5 & 100.0 & 8.2 & 21.7 & 22.2 & 47.9 & 100.0 \\
\hline LMI & 1.8 & 6.9 & 14.4 & 76.9 & 100.0 & 2.6 & 13.1 & 24.4 & 59.9 & 100.0 \\
\hline UMI & 1.0 & 6.4 & 12.3 & 80.3 & 100.0 & 1.2 & 12.8 & 19.4 & 66.7 & 100.0 \\
\hline \multirow[t]{2}{*}{$\mathrm{HI}$} & 0.5 & 4.3 & 12.7 & 82.5 & 100.0 & 0.5 & 7.0 & 22.7 & 69.8 & 100.0 \\
\hline & \multicolumn{10}{|c|}{ Imports } \\
\hline $\mathrm{LI}$ & 1.9 & 14.0 & 24.1 & 60.0 & 100.0 & 3.6 & 23.7 & 34.1 & 38.6 & 100.0 \\
\hline LMI & 0.7 & 5.7 & 19.2 & 74.4 & 100.0 & 0.9 & 10.3 & 36.7 & 52.1 & 100.0 \\
\hline UMI & 0.5 & 4.7 & 13.2 & 81.5 & 100.0 & 0.5 & 9.1 & 27.0 & 63.4 & 100.0 \\
\hline $\mathrm{HI}$ & 0.4 & 4.1 & 15.2 & 80.3 & 100.0 & 0.3 & 6.5 & 29.2 & 64.1 & 100.0 \\
\hline
\end{tabular}

LI - low-income economies; LMI - lower-middle-income economies;

$\mathrm{UMI}$ - upper-middle-income economies; $\mathrm{HI}$ - high-income economies.

Source: own calculations based on UNCTAD database (2020).

Table 3. Changes in merchandise export matrix between 1995 and 2018, by degree of manufacturing

\begin{tabular}{|c|c|c|c|c|c|c|c|c|}
\hline \multirow[b]{2}{*}{ Economy group } & \multicolumn{4}{|c|}{$1995=100$, constant 2018 US\$ } & \multicolumn{4}{|c|}{ Respective index ratios } \\
\hline & LI & LMI & UMI & HI & LI & LMI & UMI & HI \\
\hline & \multicolumn{8}{|c|}{ Labor-intensive and resource-intensive manufactures } \\
\hline $\mathrm{LI}$ & 37 & 21 & 8 & 7 & 1.0 & 0.4 & 0.0 & 0.1 \\
\hline LMI & 54 & 87 & 84 & 41 & 2.6 & 1.0 & 0.2 & 0.2 \\
\hline UMI & 166 & 354 & 190 & 72 & 21.1 & 4.2 & 1.0 & 0.5 \\
\hline \multirow[t]{2}{*}{$\mathrm{HI}$} & 96 & 173 & 145 & 107 & 12.9 & 4.2 & 2.0 & 1.0 \\
\hline & \multicolumn{8}{|c|}{ Low-skill and technology-intensive manufactures } \\
\hline $\mathrm{LI}$ & 49 & 29 & 22 & 4 & 1.0 & 0.4 & 0.1 & 0.1 \\
\hline LMI & 68 & 120 & 37 & 89 & 2.4 & 1.0 & 0.2 & 0.4 \\
\hline UMI & 182 & 237 & 143 & 109 & 8.4 & 6.4 & 1.0 & 0.4 \\
\hline \multirow[t]{2}{*}{$\mathrm{HI}$} & 58 & 215 & 243 & 170 & 14.5 & 2.4 & 2.2 & 1.0 \\
\hline & \multicolumn{8}{|c|}{ Medium-skill and technology-intensive manufactures } \\
\hline $\mathrm{LI}$ & 43 & 19 & 14 & 14 & 1.0 & 0.2 & 0.1 & 0.1 \\
\hline LMI & 111 & 148 & 108 & 131 & 5.9 & 1.0 & 0.3 & 0.6 \\
\hline UMI & 178 & 331 & 296 & 162 & 12.9 & 3.1 & 1.0 & 0.5 \\
\hline \multirow[t]{2}{*}{$\mathrm{HI}$} & 155 & 224 & 307 & 168 & 10.8 & 1.7 & 1.9 & 1.0 \\
\hline & \multicolumn{8}{|c|}{ High-skill and technology-intensive manufactures } \\
\hline $\mathrm{LI}$ & 23 & 18 & 8 & 12 & 1.0 & 0.2 & 0.1 & 0.0 \\
\hline LMI & 111 & 103 & 187 & 110 & 6.3 & 1.0 & 0.5 & 0.3 \\
\hline UMI & 147 & 361 & 251 & 143 & 19.2 & 1.9 & 1.0 & 0.3 \\
\hline $\mathrm{HI}$ & 298 & 389 & 452 & 176 & 24.5 & 3.5 & 3.2 & 1.0 \\
\hline
\end{tabular}

Source: own calculations based on UNCTAD database (2020).

The right part of Table 2 contains the index ratios, which have been calculated as quotient of merchandise export changes for economy group and its respective partner. The 
higher ratio value, the higher given economy group's export rate in comparison with respective partner exports change. It's quite obvious than middle and high income economies have high ratio values for merchandise exports to low income countries. On the contrary, with the higher degree of manufacturing high economies advantage is not so explicit - the ratio values concerning high income countries exports to lower and upper middle income countries are in the range between 2 and 4, the highest in labor-intensive and resource-intensive manufactures (high income countries exports to lower middle income economies) and high-skill and technology-intensive manufactures (high income countries exports to lower and upper middle income economies).

\section{The importance of middle income countries in international trade: analysis of selected indicators}

The role of middle income countries in international trade can be analyzed on the basis of different indicators, but due to paper limitations only selected ones have been included herein. The first is average export rate, presented in Figure 2 for 1995-2018. Except the low income economies, for which the export rate values were the lowest and have presented noticeably downward trend since 2005, this indicator values for middle and high income economies were quite similar. Moreover, in 2000-2008 difference between high income and upper middle income economies was the highest, in favor of the latter. In last decade such difference was really small and for both country groups average export rate varied between 0.2 and 0.25 .

International division of labor engagement index is a general measure of industrial production specialization degree of given country, which in turn can be understood as an extent of its participation in international trade. The lower this measure value, the smaller country's engagement in international division of labor and participation in international trade. Data presented in Figure 3 show that in period under scrutiny only high income economies were steadily increasing their engagement in international division of labor, especially in last decade, when the indicator value grew from 1.2 in 2007 to 1.8 in 2017. In contrast to them, in last twenty years engagement index value for low income economies decreased more than twofold, from 1.8 to 0.7 , which could be caused by their persisting specialization mostly in primary commodities production and exports. And again, amongst middle income economies the upper middle income ones have shown evident upward trendmore than twofold growth (from 0.5 to more than 1.0) in the period considered.

Trade coverage indices for primary commodities and merchandise by degree of manufacturing have been presented in Table 4. Values greater than 1 mean that particular economy group has gained competitive advantage against abroad. In 1995 low and middle income countries had competitive advantage in primary commodities and labor-intensive and resource-intensive manufactures. On the other hand, high income countries achieved such advantage in all groups of skill and technology-intensive manufactures.

After more than two decades situation has changed dramatically. First of all, low and high income economy groups recorded the indicator decline in trade of almost all goods. Moreover, they retained tiny competitive advantage in terms of trade coverage only in trade of primary commodities and high-skill and technology-intensive manufactures, respectively. Lower middle income economies' competitive advantage worsened for primary commodities and labor-intensive and resource-intensive manufactures, but was slightly better for skill and technology-intensive manufactures. Upper middle income economies 
improved in all goods but primary commodities, and their competitive advantage increased especially in labor-intensive and resource-intensive manufactures, but also to a large degree in low- and medium-skill and technology-intensive manufactures.

\subsection{5}

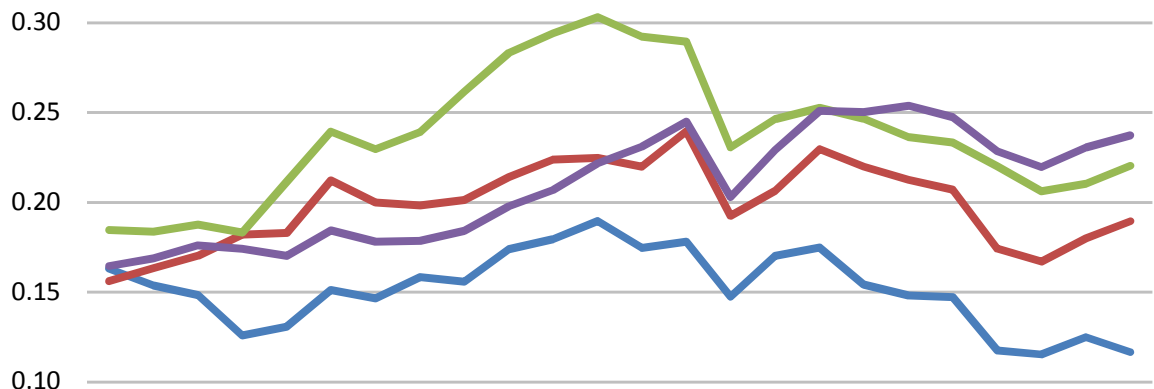

0.05

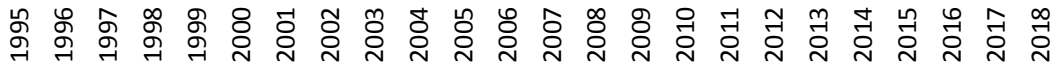

Low-income economies

Lower-middle-income economies

Upper-middle-income economies

High-income economies

Figure 2. Average export rates in 1995-2018

Source: own calculations based on UNCTAD database (2020).

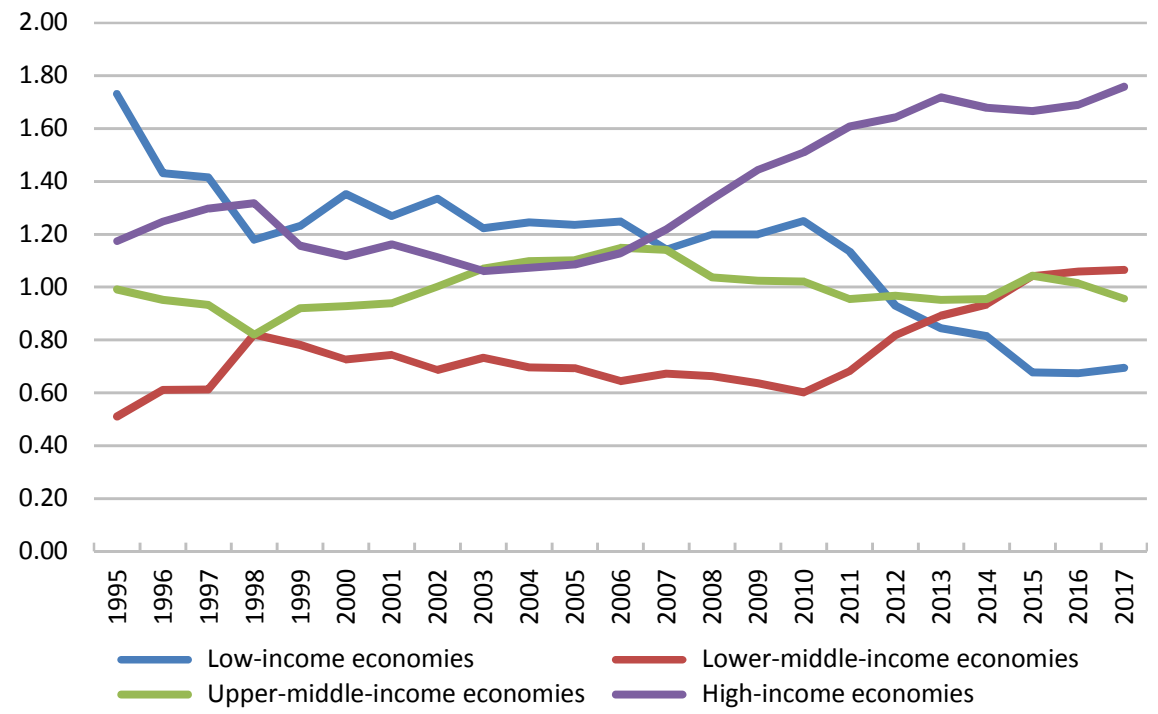

Figure 3. International division of labor engagement index in 1995-2018 Source: own calculations based on UNCTAD database (2020). 
Table 4. Trade coverage indices in 1995 and 2018

\begin{tabular}{|c|c|c|c|c|c|}
$\begin{array}{r}\text { Product } \\
\text { groups } \\
\text { groups }\end{array}$ & $\begin{array}{c}\text { Labor-inten- } \\
\text { Primary com- } \\
\text { modities }\end{array}$ & $\begin{array}{c}\text { Low-skill and } \\
\text { source-inten- } \\
\text { sive manu- } \\
\text { tactures }\end{array}$ & $\begin{array}{c}\text { Medium-skill } \\
\text { intensive } \\
\text { manufac- } \\
\text { tures }\end{array}$ & $\begin{array}{c}\text { High-skill and } \\
\text { and technol- } \\
\text { ogy-intensive } \\
\text { manufac- } \\
\text { tures }\end{array}$ & $\begin{array}{c}\text { technology- } \\
\text { intensive } \\
\text { manufac- } \\
\text { tures }\end{array}$ \\
\hline \multicolumn{5}{|l|}{1995} \\
\hline $\mathrm{LI}$ & 1.77 & 0.48 & 0.19 & 0.06 & 0.21 \\
\hline $\mathrm{LMI}$ & 1.32 & 2.33 & 0.50 & 0.18 & 0.38 \\
\hline $\mathrm{HI}$ & 1.66 & 1.75 & 0.94 & 0.51 & 0.68 \\
\hline $\mathrm{LI}$ & 0.82 & 0.86 & 1.10 & 1.13 & 1.05 \\
\hline $\mathrm{LMI}$ & 1.01 & 0.27 & 0.12 & 0.07 & 0.12 \\
\hline $\mathrm{UMI}$ & 0.89 & 1.87 & 0.57 & 0.43 & 0.57 \\
\hline $\mathrm{HI}$ & 0.96 & 2.75 & 1.61 & 1.18 & 0.92 \\
\hline
\end{tabular}

Source: own calculations based on UNCTAD database (2020).

Table 5. Changes of revealed comparative advantage (RCA) index between 1995 and 2018

\begin{tabular}{|c|c|c|c|c|c|}
\hline $\begin{array}{r}\text { Product } \\
\text { groups }\end{array}$ & $\begin{array}{c}\text { Primary com- } \\
\text { modities }\end{array}$ & $\begin{array}{l}\text { Labor-inten- } \\
\text { sive and re- } \\
\text { source-inten- } \\
\text { sive manu- } \\
\text { factures }\end{array}$ & $\begin{array}{c}\text { Low-skill and } \\
\text { technology- } \\
\text { intensive } \\
\text { manufac- } \\
\text { tures }\end{array}$ & $\begin{array}{l}\text { Medium-skill } \\
\text { and technol- } \\
\text { ogy-intensive } \\
\text { manufac- } \\
\text { tures }\end{array}$ & $\begin{array}{l}\text { High-skill and } \\
\text { technology- } \\
\text { intensive } \\
\text { manufac- } \\
\text { tures }\end{array}$ \\
\hline & \multicolumn{5}{|c|}{1995} \\
\hline $\mathrm{LI}$ & 3.45 & 0.64 & 0.44 & 0.08 & 0.18 \\
\hline LMI & 2.11 & 2.10 & 0.70 & 0.20 & 0.34 \\
\hline UMI & 1.64 & 1.37 & 1.07 & 0.56 & 0.70 \\
\hline \multirow[t]{2}{*}{$\mathrm{HI}$} & 0.84 & 0.89 & 1.00 & 1.11 & 1.08 \\
\hline & \multicolumn{5}{|c|}{2018} \\
\hline $\mathrm{LI}$ & $2.94(\downarrow)$ & 0.64 & $0.40(\downarrow)$ & 0.12 (个) & 0.18 \\
\hline LMI & $1.57(\downarrow)$ & $2.21(\uparrow)$ & 0.87 (个) & 0.45 (个) & 0.65 (个) \\
\hline UMI & $1.02(\downarrow)$ & $1.48(\uparrow)$ & $1.20(\uparrow)$ & $0.93(\uparrow)$ & $0.89(\uparrow)$ \\
\hline $\mathrm{HI}$ & $0.93(\uparrow)$ & $0.69(\downarrow)$ & $0.93(\downarrow)$ & $1.09(\downarrow)$ & 1.08 \\
\hline
\end{tabular}

Arrow in parenthesis shows change direction between 1995 and 2018.

Source: own calculations based on UNCTAD database (2020).

Confirmation of such trends can be found in Table 5, where changes of RCA index have been presented. In comparison with 1995 results, low-income economies' comparative advantage has been retained only for primary commodities. High income countries' comparative advantage diminished for nearly all goods, and values slightly higher than 1 for medium- and high-skill and technology-intensive manufactures cannot be considered as a success. Revealed comparative advantage of middle income economies improved significantly in all manufactures, and was especially high in labor-intensive and resource-intensive manufactures (both lower and upper income countries), as well as in low-skill and technology-intensive manufactures (upper middle income economies). It is possible that administrative restrictions in the area of trade relations with overseas, such as potential 
and effective trade wars between the US, China and the EU, as well as problems with new trade agreement implementation (like Trans-Pacific Partnership) have led to middle income economies RCA deterioration (Gryczka, 2020; Żołądkiewicz, 2017).

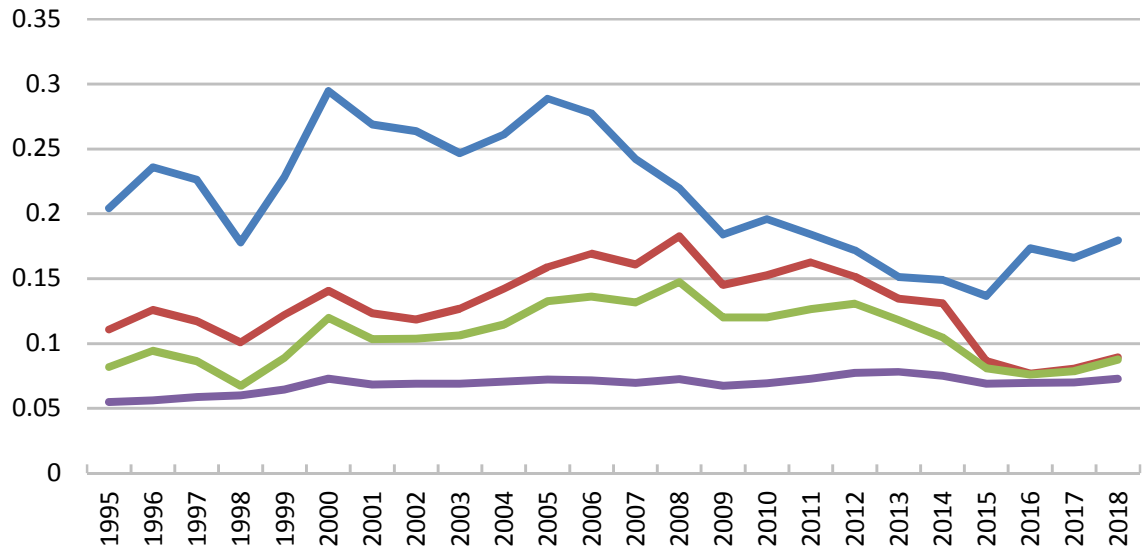

0.16

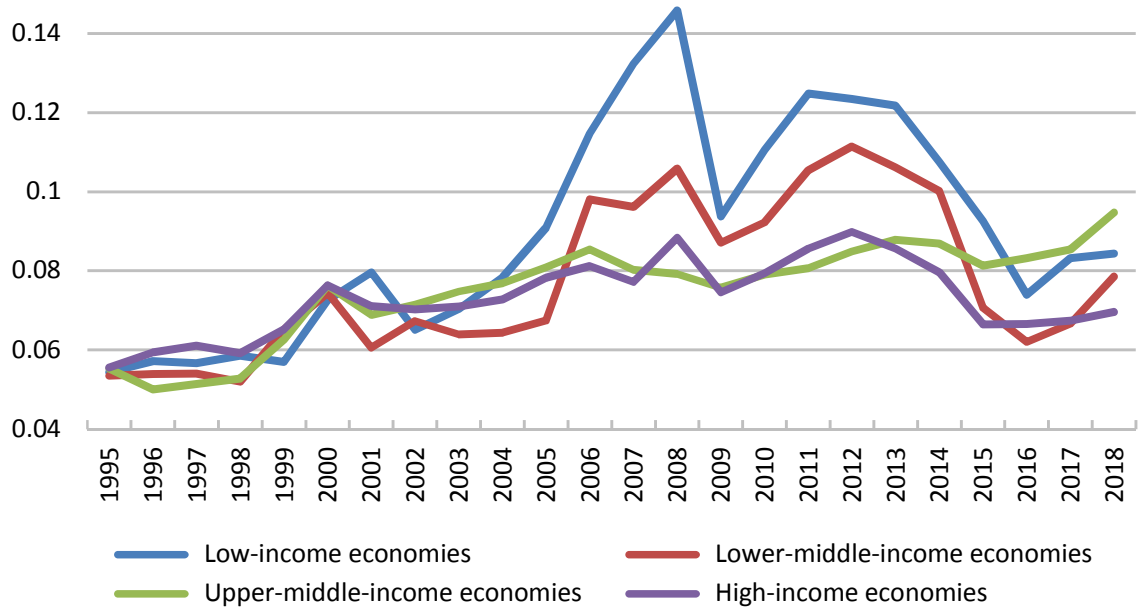

Figure 4. Product concentration indices (product HHI) of exports (upper chart) and imports (lower chart) in 1995-2018

Source: UNCTAD database (2020).

Concentration index, also named Herfindahl-Hirschmann Index, has been presented in Figure 4. This index value closer to 1 indicates a country's exports or imports are highly concentrated on a few products (on the contrary, values closer to 0 reflect exports or imports are more homogeneously distributed among a series of products). In 1995-2018 low income economies had the highest $\mathrm{HHI}$ values of exports, but they never crossed the level 
of 0.3. Actually, in last decade product $\mathrm{HHI}$ of exports for low and middle income economies were gradually decreasing, reaching in case of middle income countries values very close to those of high income economies.

Product concentration indices of imports for all economy groups were relatively low in period under scrutiny, and followed the same pattern. The major distinctions were visible mostly in 2005-2015 period, but recent values between 0.06 and 0.09 should be treated as a quite obvious proof of homogenous import distribution among the products.
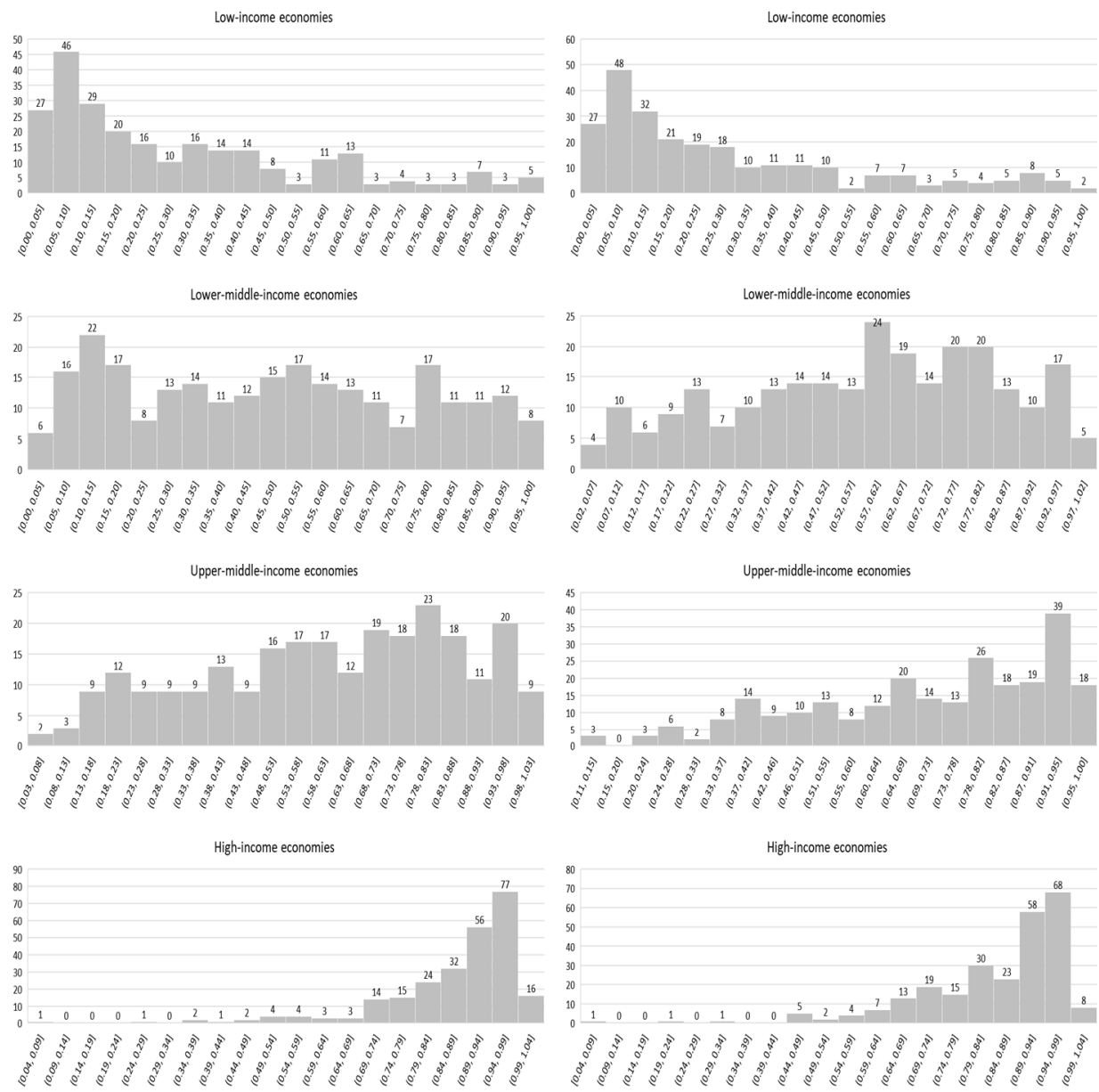

Figure 5. Distribution of intra-industry trade (IIT) index values in 1995 (left charts) and 2018 (right charts)

Source: own calculations based on UNCTAD database (2020).

Values of intra-industry trade index (IIT) for particular economy groups have been presented in Figure 5. This measure, also called Grubel-Lloyd Index, can range from 0 to 1 , and IIT=0 means that there is no intra-industry trade, only inter-industry one. The closer IIT to 1 , 
the higher share of intra-industry trade in global overseas turnover of given country or industry. In 1995 there was mostly inter-industry trade in most of products traded by low income and lower middle income economies (i.e. IIT values lower than 0.5). The situation didn't change considerably in $\mathbf{2 0 1 8}$ for low income economies, but there was an improvement for lower middle income countries, which IIT for majority of products increased to 0.6-0.9.

As concerns upper middle income countries, there was the most visible shift from interindustry to intra-industry trade. IIT distribution was quite uniform in 1995, but after two decades IIT values for more than a half of products were in range from 0.8 to 1.0 . It could be expected that distribution for high income economies remained almost the same, but substantial number of products in range $0.6-0.8$ implies that their foreign trade is less intra-industry in nature than in the recent past.

\section{CONCLUSIONS}

On the basis of conducted research the following final conclusions can be formulated:

1. Between 1995 and 2018 there was a noticeable improvement of middle income countries' share in global merchandise trade. This was mostly attributed to the recent economic achievements of BRICS countries, especially China, and of upper middle income economies in general. These economies have intensified merchandise trade among themselves and with high income group, and also increased their exports in all merchandise groups, especially in low- and medium-skill and technology-intensive manufactures.

2. Although in 1995-2018 high income countries' engagement in international division of labor was still high and indisputable, the competitive advantage of middle income economies improved dramatically. Upper middle income economies increased their competitive advantage especially in labor-intensive and resource-intensive manufactures, but also in low- and medium-skill and technology-intensive manufactures.

3. High income countries' comparative advantage measured by RCA index diminished for nearly all goods. On the other hand, middle income economies improved significantly in all manufactures, and their RCA values were particularly high in labor-intensive and resource-intensive manufactures, as well as in low-skill and technologyintensive manufactures.

4. Positive trends concerning middle income countries have been also proved by respective Herfindahl-Hirschmann Index and Grubel-Lloyd Index changes. Especially in last decade product $\mathrm{HHI}$ of exports for countries in question reached levels very close to those of high income economies, which meant their exports was much more homogeneous than a few decades ago. Another important feature of upper middle income countries was growing number of products with high ITT values, indicating their transition to intra-industry trade.

Recommendations and implications: Taking into consideration contemporary global problems, namely coronavirus pandemic, many significant negative effects can be expected to occur not only in 2020, but also in the years to come. One of severe consequences could be shortening and re-orientation of global supply chains. In this respect weakening role of China as a "global factory" can be perceived, but alternatively other middle income economies, i.e. non-Asian ones, can possibly benefit from this situation, if manufacturing were transferred closer to the final consumer markets. On the other hand, 
pandemic-related shifts in global economy and international trade can result, among others, in foreign direct investment decline and trade protectionism boost, thereby impeding the process of catching up with developed, high income countries.

Research limitations: Lack of long term statistical data can be perceived as the main limitation of the further research. Moreover, some socio-economic indicators are based on the surveys, so it's quite obvious that such data are unobtainable especially for low and lower middle income economies.

Suggestions for further research are as follows: The analysis of middle income economies' developments in the context of post-COVID19 global economy should play a predominant role in the further investigations. Green energy revolution, sustainable growth, demography-related issues, climate change implications for middle income countries and their involvement in the Fourth Industrial Revolution (Industry 4.0) are another interesting areas for future research.

\section{REFERENCES}

Bruckner, M. (2012). Climate change vulnerability and the identification of least developed countries [CDP Background Paper]. United Nations, Department of Economics and Social Affairs.

Bulman, D., Eden, M., \& Nguyen, H. (2016). Transitioning from Low-Income Growth to High-Income Growth: Is There a Middle-Income Trap?. ADBI Working Paper 646. Tokyo: Asian Development Bank Institute.

Cornell University, INSEAD,\& WIPO (2019). The Global Innovation Index 2019: Creating Healthy Lives - The Future of Medical Innovation. Ithaca, Fontainebleau, and Geneva.

Dicken, P. (2011). Global Shift. Mapping the Changing Contours of the World Economy (6 $6^{\text {th }}$ ed.). London: SAGE.

Department of Economic and Social Affairs (2013). World Economic and Social Survey 2013. Sustainable Development Challenges. United Nations.

Felipe, J., Kumar, U., \& Galope, R. (2014). Middle-Income Transitions: Trap or Myth? ADB Economics Working Paper Series No. 421.

Fischer, G., Shah, M.M., \& van Velthuizen, H.T. (2002). Climate Change and Agricultural Vulnerability. IIASA.

Ghosh, S.R. (1996). Reverse Linkages: The Growing Importance of Developing Countries. Finance \& Development, March, 38-41.

Griffith, B. (2011). Middle-income trap. In R. Nallari, S. Yusuf, B. Griffith, \& R. Bhattacharya (Eds.), Frontiers in Development Policy (pp. 39-43). Washington, D.C.: The World Bank.

Gryczka, M. (2020). Should the Majority of Economies Be still Treated as "Developing" - Selected Socioeconomic Indicators Analysis Based on Long-Term Data. In E. Bilewicz, J. Brzyska, M. Gryczka, \& R. Knap, International economic flows in the era of global uncertainty (pp. 129149). Szczecin: Wydawnictwo Naukowe Uniwersytetu Szczecińskiego.

Hanson, G.H. (2012). The Rise of Middle Kingdoms: Emerging Economies in Global Trade. Journal of Economic Perspectives, 26 (2), 41-64.

Lee, D., \& Zhang, H. (2019). Export Diversification in Low-Income Countries and Small States: Do Country Size and Income Level Matter? IMF Working Paper. International Monetary Fund.

Mertz, O., Halsnæs, K., Olesen, J.E., \& Rasmussen, K. (2009). Adaptation to Climate Change in Developing Countries. Environmental Management (New York), 43(5), 743-752. 
Nakonieczna-Kisiel, H. (2010). Makroekonomiczne aspekty handlu zagranicznego. In J. Dudziński (Ed.), Podstawy handlu zagranicznego (pp. 47-70). Warszawa: Difin.

O'Sullivan, A., \& Sheffrin, S.M. (2003). Economics: Principles in Action. Needham, Mass.: Prentice Hall.

Prydz, E.B., \& Wadhwa, D. (2019). Classifying countries by income. Received from https://datatopics.worldbank.org/world-development-indicators/stories/the-classification-of-countries-by-income.html (accessed: 14.03.2020).

Sposi, M., Yi, K., \& Zhang, J. (2018). Accounting for Structural Change Over Time: A Case Study of Three Middle-Income Countries. Economic Dynamics Meeting Paper 1141.

Su, D., \& Yao, Y. (2016). Manufacturing as the key engine of economic growth for middle-income economies. ADBI Working Paper No. 573. Tokyo: Asian Development Bank Institute.

UNCTAD (2020). Trade Indicators. Received from https://unctadstat.unctad.org/wds/ReportFolders/reportFolders.aspx (accessed: 17.03.2020).

United Nations Statistics Division (2019). Standard country or area codes for statistical use: Developed Regions. Received from https://unstats.un.org/unsd/methodology/m49/ (accessed: 17.03.2020).

Van Grasstek, C. (2013). The History and Future of the World Trade Organization. Geneva: World Trade Organization.

World Bank (2019). World Development Indicators 2019. Received from https://datacatalog.worldbank.org/dataset/world-development-indicators (accessed: 12.03.2020).

World Bank (2020a). How does the World Bank classify countries? Received from https://datahelpdesk.worldbank.org/knowledgebase/articles/378834-how-does-the-world-bank-classifycountries (accessed: 14.03.2020).

World Bank (2020b). How are the income group thresholds determined? Received from https://datahelpdesk.worldbank.org/knowledgebase/articles/378833-how-are-the-income-group-thresholds-determined (accessed: 14.03.2020).

WTO (2016). World Trade Statistical Review 2016. World Trade Organization.

WTO (2019). World Trade Statistical Review 2019. World Trade Organization.

Żołądkiewicz, K. (2017). Porozumienie Transpacyficzne (TPP) bez Stanów Zjednoczonych. Studia $i$ Prace WNEIZ US, 49(2), 105-115. 


\section{Author}

\section{Marcin Gryczka}

Master of Science in Sea Engineering (Szczecin University of Technology, Poland); PhD in Economics - specialization: Foreign Trade (University of Szczecin, Poland). His research interests include foreign trade and international economics, technology transfer and knowledge diffusion in digital era, e-commerce, middle income countries' role in global economy, Industry 4.0.

Correspondence to: Marcin Gryczka, PhD, University of Szczecin, Faculty of Economics, Finance and Management, ul. Mickiewicza 64, 71-101 Szczecin, Poland, e-mail: marcin.gryczka@usz.edu.pl

ORCID (1) http://orcid.org/0000-0002-8437-3183

\section{Acknowledgements and Financial Disclosure}

The project funded under program of Minister of Science and Higher Education called "Regionalna Inicjatywa Doskonałości" in the years 2019-2022, project no. 001/RID/2018/19, amount of funding: 10,684,000.00 PLN.

The author would like to thank the anonymous referees for their useful comments, which allowed to increase the value of this article.

\section{Copyright and License}

This article is published under the terms of the Creative Commons

Attribution - NoDerivs (CC BY-ND 4.0) License

http://creativecommons.org/licenses/by-nd/4.0/

Published by Cracow University of Economics - Krakow, Poland 
